\title{
THE MUTUAL AID PACT OF THE AIRLINE INDUSTRY
}

\author{
VERNON M. BRIGGS, JR.
}

$\mathrm{O}^{n}$ N OCTOBER 30,1958 , representatives of six of the nation's twelve domestic trunk-line carriers and one international carrier signed an agreement, effective retroactively to October 20, 1958, establishing a program for the partial protection of struck participants against the normal economic losses associated with a strike period. ${ }^{1}$ The plan is known as the "Mutual Aid Pact." The original six carrier signatories ${ }^{2}$ and the four other trunk-line carriers ${ }^{3}$ who later joined the pact usually account for approximately 90 percent of the annual trunk-line traffic carried in the nation. 4

Under the provisions of Section 412 (b) of the Federal Aviation Act, ${ }^{5}$ carriers are obligated to present such agreements to the Civil Aeronautics Board (CAB) for review. The $\mathrm{CAB}$, in turn, is required to rule as to whether or not the objectives of such agreements are adverse to the "public interest."' On May 20, 1959, the $\mathrm{CAB}$, in a four to one vote, extended its

Multiemployer unionism poses difficult problems of bargaining strategy for employers exposed to the hazards of the "whipsaw" or divide-andconquer tactic used by some unions. This circumstance has resulted in employer experimentation with various mutual assistance arrangements. One such scheme, the Mutual Aid Pact worked out by a number of carriers in the airline industry, is described in this article.

The author is assistant professor of economics at the University of Texas. He wishes to express his indebtedness to Charles C. Killingsworth for his detailed comments on an earlier version of this article.-Ediron approval to the pact subject to the deletion of a single clause that required a struck carrier to refer its customers to the available flights of other pact participants. This original approval, however, was granted by the CAB without the benefit of an evidentiary investigation.

Within a year after the initial $\mathrm{CAB}$ ruling, the coverage conditions of the pact were broadened with the result that four other carriers joined the original six as participants. The combination of the enlarged scope of the agreement, the extended application of its membership, and the filing of a detailed list of objections by six of the major labor unions in the industry led the $\mathrm{CAB}$ to reconsider its earlier passive position. On June 20, 1960 , the $\mathrm{CAB}$ ordered a thorough investigation. A long and detailed record was developed over the following fouryear period. On July 10,1964, the CAB

'See "Joint Exhibits of the Airline Parties," vol. I, C.A.B. Docket 9977 (March 31, 1962), Joint Exhibit No. 1, pp. 1-6, for a detailed account of the fifteen days immediately preceding the sign. ing of the pact.

${ }^{2}$ American Airlines, Inc., Capital Airlines, Inc., Eastern Airlines, Inc., Pan American World Airlines, Inc., Trans World Airlines Inc., and United Air Lines, Inc.

${ }^{3}$ Braniff Airways, Inc., Continental Air Lines, Inc., National Airlines Inc. (National no longer is a member), and Northwest Airlines, Inc.

'Civil Aeronautics Board Order No. E-15413, p. 3 .

549 U.S.C. 1382.

${ }^{\circ} 49$ U.S.C. 1302. 
- in a split vote of three in favor, one opposed, and one in favor in part and opposed in part - granted approval to the pact for a limited three-year period.

\section{Labor Relations in the Industry}

Before discussing the Mutual Aid Pact itself, it is important to comment briefly upon the general nature of labor relations in the industry. Unquestionably, the dominant feature of virtually every aspect of this industry is the degree of direct and indirect involvement of the federal government. ${ }^{7}$ The beginning of public regulation of industrial relations in the airline industry dates back to 1936 when Title II was added as an amendment to the Railway Labor Act. The amendment ${ }^{8}$ extended virtually all of the provisions applicable to railway labor relations under Title $I$ of that act to the airline industry. Later, in 1938, the Civil Aeronautics Act $^{\theta}$ was passed, which required that any carrier desiring to secure and to retain a certificate of convenience and necessity from the CAB must comply with Title II of the Railway Labor Act. ${ }^{10}$

The application of the Railway Labor Act to labor negotiation in the industry has meant that a detailed apparatus for seeking to minimize the likelihood of an actual strike has been superimposed upon the bargaining situation. The bargaining participants are required to progress through a series of prescribed steps each of which is designed to enhance the opportunity for a settlement at that stage. These steps include obligatory conferences between the parties; mediation attempts through the auspices of the National Mediation Board (NMB); use

\footnotetext{
'Mark L. Kahn, "Regulatory Agencies and Industrial Relations: The Airlines Case," American Economic Review, May 1952, pp. 686-698.

849 Stat. 1189.

${ }^{8} 52$ Stat. 977.

1052 Stat. 990.
}

of bipartisan systems boards of adjustments - which, if deadlocked, may employ a neutral referee-to proffer binding settlements of unresolved grievances and disputes rising out of the interpretation of the terms of existing contracts; voluntary arbitration of issues pertaining to new contract terms; and the establishment of presidential emergency boards to ascertain the exact questions in dispute and, generally, to tender recommendations for terms of settlement.

Labor-management relations have developed against this backdrop. The first major union in the airline industry was the Air Line Pilots Association, formed in 1931, but trade unionism did not come in the non-pilot occupations until the early forties. Following the war, the rapid growth of the industry was accompanied by intensive unionization of all categories except the white-collar occupations. Currently, there are nine national unions that represent the major job classifications that bargain with the eleven domestic trunk lines ${ }^{11}$ and one international carrier. ${ }^{12}$ Most carriers also bargain with several other minor unions representing various occupational groups. Hence, multiple unionism is a key feature of the bargaining environment.

Multiple unionism has been a constant source of industrial instability. ${ }^{13}$ Aside from encouraging interunion competition over bargaining accomplishments and objectives, the primary disruptive feature associated with multiple union-

\footnotetext{
${ }^{11}$ The number of domestic trunk-lines was reduced to eleven on June 1, 1961, when Capital merged with United.

${ }^{12}$ For a listing of the certified employee representatives for each occupation on each individual carrier, see Twenty-ninth Annual Report of the National Mediation Board (Washington: G.P.O., 1963), p. 94.

${ }^{13}$ See Edward B. Shils, "Transportation's Labor Crisis," Harvard Business Review, May 1964, pp. 84-98.
} 
ism is that it greatly increases strike exposure. The numerous contracts, negotiation sessions, contract expiration dates, strike threats, and jurisdictional controversies all contribute to the increased possibility that an actual strike will occur, and in most instances, a strike by any one of the numerous unions can shut down the entire operations of a firm. In addition, the presence of rival unions at the individual job level has tended to compound these difficulties.

In almost every instance, collective bargaining is conducted on a single-carrier and single-union basis. The dissimilar operating problems of the different carriers have been contributing factors in this development. Differences in time schedules, route patterns, and types of equipment have given rise to unique issues with each carrier. ${ }^{14}$ Another factor has been the craft unionism that has grown out of the Railway Labor Act, under which a major function of the National Mediation Board is to resolve employee representation disputes. The NMB is required, upon the request of any party to such dispute, to designate who is to participate in a certification election. The standard relied upon by the Board in making such decisions is the so-called "majority rule provision" of the act. Under this doctrine, "the majority of any craft or class of employees shall have the right to determine who shall be the representative of the craft or class for the purposes of the Act."15 This representation provision of the act was imposed upon the airline employees at a time when the industry itself was in its infancy. In virtually all other industries in the nation - including the railroads

\footnotetext{
"Mark L. Kahn, "Mutual Strike Aid in the Airline Industry," Papers Presented at the 1960 Spring Meeting of the Industrial Relations Research Association, May 1960, p. 576.

${ }^{15}$ Title I, sec. 2, par. 4. Italics added.
}

- the pattern of union organization was originally determined by the employees themselves and by the inherent labormarket characteristics of the particular industry. In the airline industry, the organizational pattern was decreed by Congress. The continued reliance upon the "craft or class" principle would seem to guarantee that craft unionism rather than industrial unionism will prevail as the structural basis of union organization. ${ }^{16}$ Since each craft has now developed its own special problems and since several unions are rivals for the same members, the unions - with the exception of the International Association of Machinists (IAM) - have shown little interest in multiunit bargaining.

Still another influence favoring individual bargaining has been the interpretations given to the Railway Labor Act by the CAB. The Board has ruled that multiunit bargaining "cannot be imposed by any party to a dispute but must come only as a result of the consent of all parties." 17 Since in most instances it is to the advantage of one of the parties not to favor enlargement of the bargaining unit, it is usually impossible for both parties to agree to bargain in any manner other than on a single-union and singleemployer basis. Finally, there is the fact that the Air Transport Association (ATA), the industry trade association, is quite weak in its duties and powers when compared with associations in other large industries. As a result, ATA has not succeeded in providing any lasting encouragement to attempts to establish industry-wide bargaining.

The rapid inroads made by advancing technology have been a further source of

\footnotetext{
${ }^{16} \mathrm{E}$. B. McNatt, Labor Relations in the Air Transport Industry 1947-57 (Urbana: University of Illinois Press, 1958), pp. 8 and 23.

${ }_{178}$ C.A.B. 354 (1947).
} 
industrial relations difficulties. While certainly not peculiar to this industry alone, the difficulties of bargaining in an environment characterized by rapid technological change have been both numerous and onerous. On the employee side, some occupations have been created, such as the flight engineers which first appeared in 1948 with the introduction of the DC- 6 and the Constellation. In recent years, however, jobs like the flight radio officer and flight navigator have been rendered virtually obsolete. Similarly, the coming of the jet liners in 1958 has now threatened to eliminate the flight engineers. ${ }^{18}$ The pace and breadth of technological change in the industry has raised complications for all bargaining units. As for the employers, the jet age has brought many managerial problems. The switch to jet aircraft has meant extensive capital investment, increased fixed costs, rapid obsolescence of equipment, and for the first few years after the introduction of the larger and faster jets - unplanned overcapacity. Thus, the need for industrial peace in recent years has been without precedent. The likelihood of its being achieved, however, has never been dimmer.

Finally, mention should be made of the fact that airline service is extremely "time sensitive." Business inventories cannot be stockpiled prior to a strike or past orders recouped following a strike. When the service is demanded, it is needed at a specific time. If one carrier is struck, then the facilities of a competing trunk-line are generally available on the major revenue routes. Should there be no direct competitor or should the competitor be operating at full capacity, the customers

\footnotetext{
${ }^{19}$ Albert A. Blum, "Fourth Man Out - Background of the Flight Engineer-Airline Pilot Conflict," Labor Law Journal, August 1962, pp. 649 657.
}

of the struck line may switch to alternate forms of transportation or permanently cancel their plans. Consequently, air transportation is one industry today in which the strike weapon has retained its full measure of economic potency to the individual firm.

\section{Establishment of the Original Pact}

As with virtually every aspect of the pact, even its origin has been the subject of major controversy. The carriers claimed that it was a spontaneous reaction to the union use of a whipsaw tactic in a strike against Capital Airlines beginning October 17, 1958. Capital had been one of six carriers that had been engaged in a contract dispute with IAM. All six carriers had been joint parties before a single presidential emergency board (Board No. 122) proceeding before the strike. ${ }^{10}$ Capital accepted the recommendations of the Board; IAM rejected them. Capital, which was in serious financial difficulties, ${ }^{20}$ was struck while all of its competitors continued to operate (including, of course, the five other carriers involved in the dispute). Thus the carriers have stated that "the Capital strike was unquestionably the immediate event that inspired the Mutual Aid agreement."21

The union parties, on the other hand, argued that the pact had many precedents insofar as attempts at joint action by

\footnotetext{
${ }^{10}$ On only two previous occasions since the airline industry was brought under the Railway Labor Act has more than one carrier been a party in a proceeding before an emergency board. They were Board No. 36 in 1946 and No. 108 in 1955.

30" Joint Exhibits of the Airline Parties," vol. II, C.A.B. Docket No. 9977, Dec. 18, 1961, Joint Exhibit A, p. 3. Testimony of Robert J. Wilson, vice-president-personnel and properties of Capital Airlines.

21"Brief of the Carrier Parties to Examiner S. Thomas Simon," C.A.B. Docket No. 9977, p. 8; also, see "Joint Exhibits...," vol. II, Joint Exhibit $A$, p. 1 .
} 
airline employers to counter union strike actions were concerned. ${ }^{22}$ The union parties contended that as far back as 1947 the carriers had tried to establish group bargaining when the Airline Negotiating Conference was established and replaced in 1950 by the Airline Personnel Relations Conference. ${ }^{23}$ In the months prior to the actual adoption of the pact, several other devices had been seriously studied. An official of Trans World, which was about to introduce its jet equipment and was apprehensive about its effects on labor relations, had been working "for a long time" on a proposal which pertained solely to Trans World, Pan American, American, and Eastern. These four carriers were to be the first to use jet equipment. The proposal was simply that the operating competitors would pay over to a struck carrier an amount equal to the increased revenue received during the strike period. The exact details were never completed.

Another proposal was under study by officials connected with ATA. Their plan also centered upon those carriers which were soon to adopt jet service and involved the establishing of a "broad group bargaining plan" which would seek to avoid the possibility of a selective strike against one carrier by forcing the union to strike all of them. The strike against the group would be forced by having the

\footnotetext{
22" Brief of the Union Parties to Hearing Examiner S. Thomas Simon in Opposition to Approval of Mutual Aid Pact," C.A.B. Docket No. 9977, Nov. 29, 1962, pp. 28-33.

${ }^{29}$ The exact original purposes of these organizations is quite "vague" (ibid., pp. 56-57, esp. ns. 91 and 92). Both organizations have been virtually of no consequence as actual bargaining entities. The Airline Negotiating Conference went out of existence shortly after its formation without ever assuming any significant role. The Airline Personnel Relations Conference serves today solely as a body for the gathering and disseminating of statistical information relevant to industrial relations matters.
}

struck carrier lease its equipment to the remaining carriers that were operating. The pilots on the other lines would, in all likelihood, refuse to fly the equipment and the non-struck carriers would be free either to discharge the pilots or to shut down their operations due to the fact that the pilots had breached the terms of their contract. ${ }^{24}$ In this manner, group bargaining could be attained. The "group bargaining plan" was to be merged, if possible, with a "mutual insurance plan." A special company was to be established by the interested carriers in Nebraska and additional insurance coverage would be sought from Lloyds of London. ${ }^{25}$ Thus, the unions claimed that "the original Pact was in fact a step in an overall program of strike insurance and group bargaining by which the carriers were to exert increased pressure on the unions." 26

Subsequently, the Hearing Examiner concurred with the union position and held that "the record is clear that the mutual aid principle had been under consideration by the major air carriers for at least a year prior to the execution of the original Pact."'27

\section{Provisions}

The operational principle upon which the original pact was based can be stated simply, but its actual mechanics are quite complicated. In the event that a strike occurred against one of the participating carriers involving any one of the three conditions for coverage, then:

... each party will pay over to the party suffering the strike an amount equal to its increased revenues attributable to the

\footnotetext{
24"Brief of Union Parties...Examiner," pp. 29-30; also see "Initial Decision of Hearing Examiner S. Thomas Simon," C.A.B. Dockett No. 9977 (May 14, 1963), p. 58, esp. n. 96.

2s"Brief of Union Parties...," p. 30.

${ }^{28}$ Ibid., p. 34.

27"Initial Decision... Examiner...," p. 55.
} 
strike during the term thereof, less applicable added direct expense. ${ }^{28}$

These payments have subsequently been referred to as "windfall payments."

The three conditions which brought the strike within the scope of the original pact were:

1. A strike called to enforce union demands in excess of or opposed to the recommendations of a presidential emergency board appointed under Section 10 of the Railway Labor Act.

2. A strike called before exhaustion of the prestrike procedures of the Railway Labor Act.

3. A strike which is "otherwise unlawful." 29

In an earlier draft of the original version, an official from Trans World suggested two other situations which would have made the pact applicable. ${ }^{30}$ These were strikes for the purpose of compelling the employment of personnel - (1) in excess of the number required by government regulations, and (2) with training in skills not required or with greater qualifications than those required by the regulations. These two provisions were removed from the final version of the original draft "so that the agreement would be confined to the principal objectives of strengthening the procedures of the Railway Labor Act."'31

Under the original pact, the exact procedure for computing the amount of the windfall payment was determined individually by each of the carriers. Thus, each carrier devised its own definitions and its own computation formula. It is important to note that under the windfall payments provisions, the amount to

\footnotetext{
${ }^{28}$ Agreement Dated October 20, 1958, C.A.B. Docket 9977, p. 3.

${ }^{29}$ Ibid., pp. 2-3.

30"Joint Exhibits of the Airline Parties," vol. I,

C.A.B. Docket No. 9977, Joint Exhibit No. 1, p. 4.

rlbid., p. 5.
}

be turned over to the struck competitor is determined by the paying carrier.

\section{Management's Objectives and Labor's Reaction}

The carrier members have contended from the beginning that the pact is a "defensive weapon" which is needed to correct an alleged "imbalance" in bargaining power in favor of the unions. ${ }^{32}$ Essentially, the explicit carrier arguments are that the airline unions have misused their right to strike; that the airline unions have developed a multitude of collective arrangements for interunion and intraunion cooperation and concerted action; and that the loss of good will, the high poststrike costs associated with resuming normal operations, and the high fixed costs that cannot be reduced in times of shutdowns make the economic burden of a strike against a single carrier extremely severe. Also implicit in the early considerations of the pact was the fear that the introduction of the new and expensive jet aircraft would cause unrest among the unions.

When the pact became public, the airline unions bitterly assailed every aspect of it. $^{33} \mathrm{~A}$ tangible indication of the apprehension felt by the unions was their announcement in September 1959 of the proposed formation of their own mutual alliance. Subsequently, on April 12, 1960, seven airline unions ${ }^{34}$ joined together to

\footnotetext{
${ }^{32} \mathrm{E}$. g., see "Brief to the Civil Aeronautics Board," C.A.B. Docket No. 9977, Jan. 5, 1959, pp. $44 \mathrm{ff}$

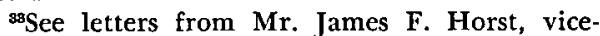
president of the Transport Workers Union (Nov. 5, 1959), Mr. George R. Petty, Jx., president of Flight Engineers Association (Nov. 4, 1959), and "Objections of International Association of Machinist" (Nov. 14, 1959) to the Civil Aeronautics Board, contained in C.A.B. Docket No. 9977.

ss The Air Line Pilots Association, the Air Dispatchers Association, the Brotherhood of Railway and Steamship Clerks, the Flight Engineers International Association, the Transport Workers Union, the International Association of Machinists, and the United Automobile Workers.
} 
form the Association of Air Transport Unions (AATU). It was the avowed purpose of this organization to seek a common contract expiration date for their bargaining units and to oppose the continuation of the Mutual Aid Pact by petitioning the $\mathrm{CAB}$ for a review of the plan. The fact that such rivals as ALPA and FEIA, and also IAM and TWU, would unite into this single body is but further proof of the dangers that the unions saw in the pact. Yet, despite the motivating fears that drove the unions together, their lack of unity in the past soon proved to be an insurmountable obstacle. As a result, the AATU had become inactive by November 1960 .

\section{The Coverage Problem}

Almost immediately after the adoption and implementation of the original pact, the carriers realized that the agreement was inadequate. The problem was that the limited terms of coverage of the pact were foreclosing the possibility of participation by other carriers.

The non-pact competitors were under no obligation to pay over to a struck carrier any windfall payments. Several of Eastern's direct competitors - Delta, Northeast, and National - were not in the pact; United's competitor, Western, was a non-participant; and Pan American's competitors, Northwest and Braniff, were both outside the agreement. Consequently, these lines in particular began to agitate for an expansion of membership. Eastern, in fact, threatened to pull out of the original pact unless its competitors could be induced to join. ${ }^{35}$

The essential reason why the other seven trunk-lines abstained from joining was due to the nature of the coverage conditions of the original pact. The non-

\footnotetext{
ss" Joint Exhibits...," vol. I., Appendix to Joint Exhibit 1, p. 22.
}

participants were all the smaller firms in the industry. These carriers believed that the agreement would not benefit them, since a condition for the receipt of payments was that a strike be called following the issuance of recommendations by a presidential emergency board. The smaller carriers doubted that such a Board would be convened if they were struck. Their position was reinforced by the Eisenhower Administration's alleged "policy at that time not to appoint Boards except where a strike would shut down one of the few largest carriers." 36

\section{The Amendment of March 22, 1960}

To remedy the coverage restraint which was serving to limit the participation rate, the carriers on March 22, 1960 filed an amendment which added a fourth criterion that would make a mem. ber carrier eligible for payments. Coverage of the pact was broadened to include a strike "which has been called in the absence of the establishment of such a board [i.e., a presidential emergency board] and the struck party has in all respects acted in compliance with the Railway Labor Act."'37

The immediate effect of the new coverage provision was just as the original pact members had hoped. On the same day that the amendment was filed with the CAB, Braniff, National, and Northwest officially notified the $\mathrm{CAB}$ that they had joined. Shortly afterward, on April 7, 1960, Continental also gave official notice of its membership.

The over-all effect of the amendment,

\footnotetext{
sa" Brief of the Carrier...to Examiner...," p. 11. Their view stemmed from a dispute in which the administration declined to appoint an emergency board to study a threatened strike involving Western Airlines and ALPA. A strike of 108 days ensued.

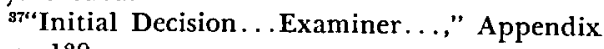
D, p. 139.
} 
however, was not merely to provide coverage for smaller firms which would not normally warrant the convening of an emergency board. It also meant that any "lawful" or "unlawful" strike against a carrier would bring the pact into operation.

Soon after the new coverage amendment was passed, the pact members found that the agreement was still not completely satisfactory. The objections were varied but they all came to the same conclusion: the windfall payments were not providing adequate protection due to financial and calculative limitations.

One of the problems came to light when Continental sustained a small strike which caused it to reduce its service, but for the most part did not affect its flight schedule. Continental requested, nonetheless, that its four competitors tender their windfall payments as required under the pact. ${ }^{38}$ The competitorsAmerican, Braniff, Eastern, and Trans World-replied that they could not discern a significant increase in their passenger revenues that could be attributed to the partial shutdown. Continental charged that:

It appeared to us that the mechanics of computing "windfall payments" were

${ }^{3}$ Both the original and the amended pact were silent on this issue of whether or not "windfall payments" were payable in partial shutdowns of service. In June 1960, a strike of Eastern's pilots in Miami, Florida, against "inflight inspection" practices of the Federal Aviation Agency led to a partial shutdown. The strike was classified as "unlawful" under the terms of the Railway Labor Act. The question of the applicability of the pact to such a situation was sent to arbitration where, subsequently, the arbitrator held that the pact did cover such circumstances and that windfall payments were required from its competitors (see "Joint Exhibits...," vol. II, Joint Exhibit No. C, p. 7). As an aside, it is of interest to note that Eastern had threatened to withdraw from the pact if partial shutdowns were not included (see "Joint Exhibits...," vol. I, Appendix 1, p. 69). such that a carrier our size could easily establish "windfall payments" for which it was obligated as a consequence of a strike on a large carrier, but, on the other hand, the large carrier could find it very difficult to identify "windfall payments" which it had obtained as a result of a strike on an airline our size. ${ }^{39}$

Consequently, Continental withdrew from the pact as of December 31, 1961.

A second source of discontent was voiced by Pan American, whose complaint stemmed from the fact that most of its competition was with foreign airlines which were not included in the pact. Thus, Pan American found itself obligated to pay out funds to its few domestic competitors but seldom receiving funds, since most of its competitors were other international carriers. Accordingly, the airline complained that it was on a "one way street."40

The third cause of dissatisfaction was that several of the domestic carriers' chief competitors still were not in the pact. Eastern's competitors - Delta, Northeast, and, as of December 31, 1961, National ${ }^{41}$ - were non-pact members. United's competitor, Western, was also outside the terms of the agreement.

A fourth insufficiency, which was of a conjectural nature, gave rise to the concern of some parties. It was quite conceivable that the competitors of a struck carrier could normally be operating at full or nearly full capacity at the time of the strike. Consequently, little, if any, windfall payments would be forthcoming.

Thus, prompted by these motivations, the stage was set for another important amendment.

\footnotetext{
${ }^{\circledR}$ Transcript of Hearings before Examiner, March 1, 1962, vol. 4, pp. 390-391.

${ }^{4}$ See, "Joint Exhibits...,"vol. I, Appendix to Joint Exhibit 1, p. 59.

${ }^{41}$ See below, pp. 1I-12.
} 


\section{The Amendment of March 26, 1962}

The carriers had actually begun inquiries into possible methods of increasing the benefits at least as far back as 1960.42 Their efforts culminated on March 26, 1962 when the members filed a new amendment to the pact which guarantees to any struck carrier that it will receive benefits totaling at least 25 percent of its "normal air transport operating expense" (called the "standard amount") ${ }^{43}$ for its operations that are shut down. To the extent that windfall payments made by the direct competitors of a struck carrier fail to meet the standard amount, additional "supplemental payments" will be made by all of the pact members. These payments will be based upon the proportion between their individual "air transport operating revenues" for the preceding calendar year and the total air transport revenues for all the participating carriers. A limitation of one-half of 1 percent (.5 percent) of "air transport operating revenue" for the previous year is established as the maximum annual liability of such payments by each carrier. In the event that the liability limitation is reached before one or more carriers has received its 25 percent, provision is made for a proportional redistribution of the supplemental payments among all of the struck carriers in that year. On the other hand, if the windfall payment should equal or exceed the standard amount, no supplemental payments will be made and the struck

\footnotetext{
42"Joint Exhibits...," vol. I, Appendix to Joint Exhibit 1, p. 39; and also pp. 40-46.

4" "Normal air transport operating expenses" for each day for any operation is defined as its average daily air transport operating expenses for such operations includable in Accounts 51007000, under the C.A.B.'s Uniform System of Accounts and Reports, for twelve months of full operation immediately prior to the month in which the strike began.
}

carrier can retain all such excess amounts over the standard amount.

Under the supplemental payments concept, the initiative rests with the struck carrier - or receiving carrier - to compute the amount to which it is entitled beyond the windfall amount. The struck carrier then notifies the other carriers of their obligations.

Continental rejoined the pact when the supplemental payments provision became effective, with the belief that, in the event of a future strike, it would now be entitled to payments regardless of the difficulties it would still encounter with respect to the windfall payments concept.

In order to close an alleged "loophole," an addition to the coverage conditions of the pact was also made at this time, a fifth criterion which makes a pact member eligible to receive payments in the event that an emergency board should be convened but fails to make recommendations for settlement.

\section{The Computation Memorandum}

\section{The Problem}

Since the supplemental payment is actually a residual difference between the standard amount and the windfall payment, it is apparent that the most important calculative aspect of the pact is the computation of this payment. For this reason, the computation process involved in determining the magnitude of the windfall payment is of major consequence to the operation of the pact.

For the first five years of the pact, the computation was left to each individual carrier to determine its own method. The lack of uniformity in procedures was bound to lead to internal difficulties. The issue came to a head following a strike against National in May 1961. The cause of the dissatisfaction arose "over the manner and methods pursued by Eastern in 
the implementation of their obligation under the Mutual Aid Pact." 44 National believed that Eastern's payment "was very much less than it should have been." 45 National was so incensed that it withdrew from membership in the pact as of December 31, 1961.

A further stimulus for the establishment of a formal and uniform procedure was provided in the hearings over the legality of the pact. The Bureau of Economic Regulation of the CAB (the Bureau) - a division of the CAB whose responsibility in formal hearings is to represent the public interest in matters that involve agreements between competing carriers - recommended the establishment of a single procedure. The decision of the Hearing Examiner concurred with this position.

\section{The Memorandum}

Given these pressures, the carriers filed a memorandum on October 29, 1963, stating that "all of the carrier parties have now adopted an identical statement of procedure for computing payments under the agreement." 46 In a twelve-page appendix to the memorandum, an outline of a single formula to compute windfall payments was presented.

Without venturing into the lengthy and specific provisions of the formula, several of its essential features should be stated. First, with regard to the computation of increased revenues by the paying carrier, five basic steps are involved:

1. Determination of the segments of the paying carrier that are competitive.

2. Selection of a representative "base period" [usually the three-week period prior to the commencement of the strike] in the interval preceding the strike for measuring traffic carried by the paying

"'Transcript...," p. 422.

${ }^{45}$ Ibid.

"Gemorandum of the Carrier Parties," C.A.B. Docket No. 9977, Oct. 29, 1963, p. 2. carrier over competitive and noncompetitive segments.

3. Measurement of the actual daily volume of traffic of the paying carrier over competitive and noncompetitive segments during the base period and during the term of the strike.

4. Computation of the excess of traffic actually carried by the paying carrier during the period of the strike above the "normal" traffic volume that it could reasonably have expected in the absence of the strike.

5. Conversion of the excess traffic into increased revenues attributable to the strike. ${ }^{47}$

Thus, the revenues received during the strike period by the paying carrier consist of all revenue generated of non-competitive segments; "normal" revenue generated over competitive segments; and the "excess" of actual revenue over "normal" revenue on competitive segments. It is this "excess," less applicable direct expenses, which is paid over to the struck carrier.

In addition to defining all of the key terms used in the computing process, the memorandum also indicates many of the numerous complications associated with the computation of the "excess" of actual revenue figure. A few of the prominent modifications to the single formula which serve to indicate the complexity of the computation task - are as follows:

1. The base period must be adjusted for seasonal and cyclical variations.

2. An allowance is made for a change in the competitive segment figure enabling it to be proportional to the change in the non-competitive segment figure over the same period - i.e., if the noncompetitive revenues increase by 5 percent for the strike period, then the competitive segment is given an allowance of a 5 percent increase which is not considered as a part of the windfall payment.

\footnotetext{
${ }^{47}$ Ibid., p. 1 of Appendix A.
} 
3. Adjustments must be made for changes in the market structure during the base period or for the strike periodsuch as the awarding of new routes to the paying carrier, the introduction of new equipment, or the opening of a new airport.

4. If more than one competing carrier is struck, then payments to each are made with regard to the segments on which they compete in proportion to the traffic carried by each in the prestrike base period.

Thus, the formula - while representing a point of common departure for all of the participants - still, of necessity, must leave an element of latitude to each carrier to compute its actual windfall payments.

Having calculated the "excess" revenue attributable to the strike of a competitor, the next step is to compute the "added direct expense" which is to be deducted from the revenue figure. To ascertain these costs, it is necessary to establish a base period (which is the calendar quarter during which the windfall payment is made) from which the "unit" costs are determined. The "units" which are measured fall into the following four categories:

1. The costs of flying the airplane, measured by wheel-off to wheel-on hours.

2. The costs of handling the airplane on the ground, measured by number of departures.

3 . The costs of handling passengers while in flight, measured by passenger miles flown.

4. The costs of handling passengers or cargo on the ground, measured by passengers carried or cargo tons lifted. 48

In addition to these traffic production costs, it is necessary to determine the additional administrative and general costs which are incurred by the paying carrier.

«abid., p. 6 of Appendix A.
Provision is also made for adjustments due to special circumstances by the individual carrier when and if they should be necessary.

\section{Challenge to the Legality of the Pact}

On April 12, 1960, the six major unions in the industry and the AATU filed a long list of objections to the pact with the $\mathrm{CAB}$. The unions, in their brief, requested the Board either to disapprove the amended pact or to conduct a full evidentiary hearing on the questions it raised.

Consequently, on June 20, 1960, the $\mathrm{CAB}$ reconsidered its earlier stand and ordered a thorough investigation. Several factors contributed to this decision. The pact had been in operation for eighteen months and facts concerning its operation were now available. In addition, the participation in the pact had been increased to the point where it included nine of the, then, twelve domestic trunkline carriers and a major U. S. international carrier. Also the coverage conditions had expanded so as to include virtually every strike in which a carrier had complied with the Railway Labor Act. Thus, holding that conditions had changed since its original approval, the $\mathrm{CAB}$ decided that "the principle of mutual assistance among air carriers had emerged as a long-term policy with implication of great impact on labor-management relations and the public interest." 49

In the lengthy proceedings before the Hearing Examiner, the union parties argued that the pact tended to spread and lengthen strikes, to force the development of counterdevices, and to create a hostile environment for the conduct of collective bargaining. For these reasons, the unions asserted that the pact tended

\footnotetext{
«" Initial Decision....Examiner...," p. 3.
} 
to defeat the purposes and intents of the Railway Labor Act.50 If true, then the pact would be harmful to the "public interest" and, therefore, in violation of the Federal Aviation Act. As a result, the unions asked that the entire pact be struck down.

The Bureau tended to take a more middle-of-the-road approach. In essence, its position was that of approving the windfall payments but opposing the supplemental payments amendment. Contending that the inclusion of the supplemental payments provision would seriously disrupt labor-management "harmony and stability" and that it would force pact members "to choose between a surrender of corporate sovereignty and a violation of the Railway Labor Act,"51 the Bureau of Economic Regulations charged that "the Pact is no longer a defensive weapon." 52 The Bureau argued that, since every pact member is obligated to pay a portion of the supplemental benefits due a struck carrier, the members will be encouraged to take common positions on major problem issues. Recalcitrant positions would be, by implication, frowned upon. Thus, the Bureau contended, impetus would be provided for unilateral group bargaining, which would be a violation of the interpretation given to the Railway Labor Act by the CAB.

The carriers replied to the above charges by contending that both the

\footnotetext{
${ }^{50}$ In their original approval of the pact, the $C A B$ held that the pact did not violate specific sections of the Railway Labor Act. Thus, in all subsequent proceedings the unions confined their legal attack to the broader issue concerning a violation of the "intended purposes" of the act.

${ }^{51 " R e p l y ~ B r i e f ~ o f ~ t h e ~ B u r e a u ~ o f ~ E c o n o m i c ~}$ Regulations to Examiner S. Thomas Simon," C.A.B. Docket No. 9977, Jan. 18, 1963, p. 2.

s2"Brief of the Bureau of Economic Regulation to the Board," C.A.B. Docket No. 9977, Oct. 10, 1963, p. 7.
}

windfall payments and the supplemental payments serve to further the "public interest," and that the pact encouraged peaceful settlements by requiring employer adherence to the procedures of the Railway Labor Act before they would be entitled to benefits. Further, they contended that the likelihood of frequent strikes - especially "unlawful" strikes under the act - is diminished. Since the unions are aware that most strikes make the pact operational, the reduced or "neutralized" economic impact of the strike weapon should mean less reliance upon the strike and more incentive for serious bargaining. ${ }^{53}$

\section{Initial Decision of the Hearing Examiner}

On May 14, 1963, Hearing Examiner S. Thomas Simon rendered his decision, a decision which rejected virtually all of the arguments of both the union parties and the Bureau. In upholding the validity of the entire pact, Simon concluded that the agreement was merely another "economic weapon" which the CAB should not attempt to regulate because such action would restrict the ability of one party to bargain effectively.

In his decision, Simon found that the primary objective of the pact was "a reduction in the number of strikes with the consequent losses to the Pact members as a group." ${ }^{64}$ Reviewing the strike history of the trunk-line carriers since the inception of the pact, he found that there had been only one strike which involved purely economic issues, stating that the pact members and non-members "have been almost continuously involved in labor disputes which have had their roots in a jurisdictional representation controversy between two major air transport

\footnotetext{
36 ff.

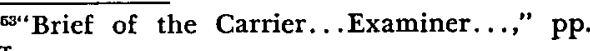

54"'Initial Decision... Examiner...," p. 97.
} 
unions representing flight crew members." 55 He denied the carriers' charge of an existing "imbalance" of economic power in favor of the unions and indicated that carriers were not "helpless" and "could have weathered their labor difficulties without catastrophic results in the absence of mutual assistance."56 Nevertheless, in a statement that seems partially contradictory, he approved the pact on the grounds that:

... The record developed by the carriers relating to the financial vulnerability of a carrier to a strike, as well as the evidence of unrestrained use of strike power by the unions in the crew complement controversy, is a justification for the adoption of the mutual assistance principle as an economic weapon for use in the collective bargaining process. ${ }^{57}$

Brushing aside the Bureau's contention that the supplemental payments section could have dire effects upon labor-management relations as being "suppositional" and as "inchoate inferences," Simon stated that he was "of the opinion that the Pact has had little or no recognizable authority upon the course which labor relations has taken during this period."58 Accordingly, he concluded that "there is no substantial evidence in the record that the Pact has had any material effect upon the collective bargaining process in the industry." 59

On July 11, 1963, the CAB exercised its right of discretionary review of the initial decision of the Examiner. ${ }^{60}$ The union parties and the Bureau had both

solbid., p. 101 .

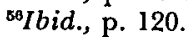

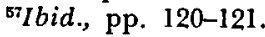

sIbid., p. 118.

59lbid., p. 119.

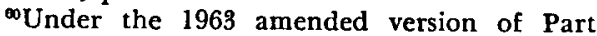
302.28(d) of the CAB's Rules of Practice in Eco. nomic Proceedings, the findings of the Examiner are final, unless there is a formal petition for review or should two or more Board members on their own initiative request a review. filed petitions requesting review; the carriers opposed the move.

In their respective briefs to the Board, the positions of the parties remained essentially the same as before. The carriers laid stronger emphasis upon the jurisdictional difficulties in the industry than they had previously. The union parties again sought a total condemnation of the plan. The Bureau requested only to have the supplemental payments provision struck from the pact.

The Decision of the CAB

On July 10, 1964, the CAB issued its decision on the legality of the pact. Three members granted approval, but their decision was not finally dispositive. A three-year trial period - until July 10, 1967 - was established. At that time, a final decision will be rendered.

The majority expressed complete agreement with the decision of the Examiner that the pact is consistent with the "public interest" provisions of the Federal Aviation Act. ${ }^{61}$ Moreover, they stated:

Air carriers are particularly vulnerable to strikes, and the industry has, in the recent past, been plagued by strikes. The Pact offers, at a not unreasonable cost for the protection obtained, a substantial measure of relief against the costs of strikes, in this fashion and to this extent contributing to industrial stability. ${ }^{62}$

Nonetheless, the majority was hesitant to state without reservation that the pact has not had some contributory effect to the general "deterioration of labor-management relations" during the recent years. For this reason, the time limitation to their approval was included. ${ }^{63}$

One member of the Board concurred in part with the majority and dissented

\footnotetext{
o1"Opinion of the Board," C.A.B. Docket No. 9977, Order E-21044, July 10, 1964, p. 4.

${ }^{62}$ Ibid., p. 5.

Ibid., p. 8.
} 
in part. Agreeing with the Bureau, he approved the part of the pact concerned with windfall payments, but opposed the supplemental payments provision. Fearing that the latter provision would encourage "involuntary joint bargaining" under "the guise of single carrier negotiation" and that it will encourage the unions to develop counterbalancing machinery, he vigorously disapproved of this portion. ${ }^{84}$

Another member dissented entirely from the opinion of the majority. Just as he had voted in the original opinion of the Board in 1959, he again disapproved of the pact "in its entirety." that there is common agreement by all members of the Board that labor relations had deteriorated in recent years, he stated that it is apparent that the unions regard the pact as a direct attack. Hence he concluded:

\footnotetext{
orIbid., p. 2 (of opinion by Vice-chairman Murphy).

sIbid., p. 1 (of opinion by Member Minetti).
}

The important thing is that the Pact has created and nurtured a spirit of distrust that is destructive of the mutual confidence and respect which is essential to the successful negotiation and solution of problems in the emotionally charged atmosphere of labor-management relations. ${ }^{66}$

\section{Effectiveness of the Pact in Meeting Carrier Objectives \\ Operations}

A comparison of the total windfall payments and windfall receipts of the participating carriers through December 31, 1962 is presented in Table 1. The table indicates the actual magnitude of the windfall payments portion of the pact, totaling over $\$ 22$ million in its first fifty months. The table also shows the breadth of the gap between the payments and the receipts of some carriers. Pan American and United paid out far more than they received; Eastern and Northwest have had the reverse experience.

${ }^{\oplus}$ Ibid., p. 4.

Table 1. Summary of "Windfall Payments" under Mutual Aid Pact, October 1958-December 31, 1962.

(thousands of dollars)

\begin{tabular}{|c|c|c|c|c|c|c|c|c|c|c|c|}
\hline \multirow{3}{*}{$\begin{array}{c}\begin{array}{c}\text { Received } \\
\text { by }\end{array} \\
(1)\end{array}$} & \multirow{3}{*}{$\begin{array}{c}\begin{array}{c}\text { Total } \\
\text { Received }\end{array} \\
(2)\end{array}$} & \multicolumn{10}{|c|}{ Amount Paid by } \\
\hline & & \multirow{2}{*}{$\begin{array}{c}A A L \\
(3)\end{array}$} & \multirow{2}{*}{$\begin{array}{c}B A L \\
(4)\end{array}$} & \multirow{2}{*}{$\begin{array}{c}C A P \\
(5)\end{array}$} & \multirow{2}{*}{$\begin{array}{c}C A L \\
(6)\end{array}$} & \multirow{2}{*}{$\begin{array}{c}E A L \\
(7)\end{array}$} & \multirow{2}{*}{$\begin{array}{c}\mathcal{N} A L \\
(8)\end{array}$} & \multirow{2}{*}{$\begin{array}{c}\mathcal{N} W A \\
(9)\end{array}$} & \multirow{2}{*}{$\begin{array}{c}P A A \\
(10)\end{array}$} & \multirow{2}{*}{$\begin{array}{c}T W A \\
(11)\end{array}$} & \multirow{2}{*}{$\begin{array}{l}U A L \\
(12)\end{array}$} \\
\hline & & & & & & & & & & & \\
\hline nang & $\$ 4,431$ & - & $\$ 169$ & $\$ 353$ & $\$ 41$ & $\$-$ & $\$-$ & $\$-\$$ & - & $\$ 1,260$ & $\$ 2,608$ \\
\hline Braniff. . & - $^{*}$ & - & - & - & - & - $^{*}$ & - & - & - & - & - \\
\hline tal.. & 2,620 & 908 & - & - & - & 301 & - & - & - & 419 & 992 \\
\hline iental. & - & - & - & - & - & - & - & - & - & - & 一 \\
\hline & 8,278 & 1,367 & 184 & 714 & 2 & - & 411 & 424 & 1,351 & 352 & 3,474 \\
\hline $\mathbf{N}$ & 107 & 4 & 1 & 26 & - & 74 & 一 & - & - & 1 & 1 \\
\hline & 3,601 & 177 & 一 & 796 & - & 115 & 一 & - & 650 & 43 & 1,820 \\
\hline Pan American. & 121 & - & 7 & - & - & - & - & - & - & - & 114 \\
\hline Trans World.. & 3,071 & 727 & 25 & 195 & 44 & 1 & - & - & 319 & - & 1,760 \\
\hline United...... & - & - & - & - & - & - & 一 & - & - & - & - \\
\hline Total Paid.. & 229 & $\$ 3,183$ & $\$ 386$ & $\$ 2,084$ & $\$ 87$ & $\$ 491$ & $\$ 411$ & $\$ 424$ & $\$ 2,320$ & $\$ 2,075$ & $\$ 10,769$ \\
\hline
\end{tabular}

Source: "Initial Decision of Hearing Examiner," C.A.B. Docket No. 9977, May 14, 1963, Appendix G, p. 150 and Appendix H, p. 151.

*Payment was less than $\$ 500$. 
Thus, it is clear why Pan American sought the adoption of the supplemental payments amendment and, as will be discussed below, why United became a strong critic of the labor relations policies of its fellow pact members.

Table 2 shows a breakdown of the total supplemental payments paid out and received since the introduction of the concept. It has been used only once - in the June 1962 strike against Eastern by the Flight Engineers. In that case, Eastern

Table 2. Summary of "Supplemental Payments" Under Mutual Aid, October 1963.

(thousands of dollars)

\begin{tabular}{|c|c|c|}
\hline Carrier & $\begin{array}{c}\text { Amount } \\
\text { Paid }\end{array}$ & $\begin{array}{l}\text { Amount } \\
\text { Received }\end{array}$ \\
\hline American...$\ldots \ldots \ldots$ & $\$ 1,061$ & - \\
\hline Braniff. .............. & 118 & - \\
\hline Continental. . . . . . . & - & 一 \\
\hline Eastern............ & - & 6,069 \\
\hline Northwest............ & 308 & - \\
\hline Pan American ......... & 1,023 & 一 \\
\hline Trans World . . . . . . . & 169 & 一 \\
\hline United.............. & 3,390 & - \\
\hline Total............ & $\$ 6,069$ & $\$ 6,069$ \\
\hline
\end{tabular}

Source: "Initial Decision of Hearing Examiner," C.A.B. Dockett No. 9977, May 14, 1963 , Appendix H, p. 151; there were no "supplemental payments" made between May 1963 and October 1964.

received $\$ 16,014,517$ in total mutual aid with $\$ 9,945,307$ representing windfall payments and $\$ 6,069,210$ representing supplemental payments.

\section{Participation and Coverage}

Currently four of the existing eleven trunk-line carriers remain outside the pact; Delta, Northeast, and Western have never shown any interest in joining the agreement, and National, the largest of the non-participants, became embittered as a pact member and withdrew. Due to a provision contained in the amended pact of March 26, 1962, National cannot rejoin the pact without making the net payments to the pact members that it would have owed had it not withdrawn. Consequently, it would appear unlikely that any of the four will join the pact in the foreseeable future. As a result, the effectiveness of the windfall payments will be diminished to the degree that would-be passengers of a struck carrier decide to use the facilities of the available non-participants. The effect of non-participants reducing the windfall payments is now, however, somewhat offset by the operation of the supplemental payments amendment.

The amended pact is currently applicable to virtually every strike situation. Only two strike circumstances would appear not to be covered: (1) if a carrier member violates the terms of the Railway Labor Act; (2) if union demands are equal to or less than the recommendations of a duly convened emergency board and the carrier refuses to accept the union's demand.

The supplemental payments concept now assumes that every participant can recoup at least 25 percent of its "normal" air transport expense for the operations that are shut down during a strike. Should the windfall exceed this 25 percent figure, the struck line would receive the additional amount. Hence, whether a struck pact member should find one or more of his direct competitors - domestic or foreign - to be non-participants is no longer of paramount importance. Each struck member is guaranteed the standard amount. While those lines that still find several of their direct competitors outside the pact may envy those carriers which can recoup an amount that exceeds the standard amount, the 
supplemental payments provision seems to have ameliorated this complaint.

\section{Liabilities and the "In and Out" Problem}

The amended pact does mean that all members assume a financial obligation whenever a fellow member is struck. As a result, the likelihood of increased interest among, the members over the varying labor policies and bargaining atmospheres of the members is far greater than would be the case in the absence of the pact. Such mutual concern may well be the source of heated controversy in the future. One such instance has already occurred. United Airlines became upset over the fact that other airlines were experiencing strikes over the ALPA-FEIA controversy, an issue that it had peacefully resolved. United, having contributed the most into the pact, threatened in April 1963 to withdraw if strikes on this same issue continued on other lines. ${ }^{67} \mathrm{As}$ the date for notification of actual intent to withdraw approached (November 1, 1963), it became apparent that United had reconsidered its position. Instrumental in this reconsideration undoubtedly, was the fact that United became a party to a major unresolved dispute with IAM which, on October 9, 1963, resulted in the establishment of a presidential emergency board. ${ }^{68}$

Membership in the pact has been in the past a source of frequent problems. Eastern (twice), Pan American, and United have at various times threatened to leave the pact; Continental withdrew only to rejoin three months later; and National pulled out entirely. In order to

a7" United Air Head Opposes Mutual Aid Strike Plan," Wall Street Journal, April 26, 1963, p. 8; see also "Patterson Favors U.A.L. Withdrawal from Strike Pact," Aviation Daily, vol. 145, April 29,1963 , p. 371 .

${ }^{88}$ The dispute was subsequently settled without a strike on Dec. 18, 1963. stabilize the participation in the pact and to prevent a carrier from joining the pact when it was advantageous and leaving when it appeared to be detrimental, a section pertinent to this subject was included in the amendments of March 1962. Withdrawal from the pact is permitted from year to year as of December $3 \mathrm{I}$, with sixty days' prior notice. But the withdrawing carrier will remain liable for all payments under agreement for a period of one year thereafter. As to joining the pact, six months prior notice is required of any applicant who has not been a member before. As for a carrier who was once a member and seeks readmittance, the carrier can rejoin only by making the net payments that it would have been required to make had it not withdrawn.

\section{Conclusions}

The approval of the pact by the CAB will not significantly alter the industrial relations environment in the industry. The true source of the turmoil of recent years has sprung from a commingling of several forces. The pact itself assumes importance not as a cause but, rather, as a result of these disruptive factors. The most dominant of these considerations is the presence of multiple unionism and of rival unionism. The perpetuation of such labor market characteristics can only mean that bitter union competition and extensive industry strike exposure will continue.

The pact itself is not going to increase the incidence of strikes. The benefits received from it are in no way competitive with the gains to be realized fom continued operation. The true significance of the pact will be revealed only after a strike has begun. When shutdowns do occur, they may tend to last longer and to be more bitter than would be the case 
if there were no pact. The Bureau has contended that it is the supplemental payments feature of the pact that will cause these undesirable results. Actually, it would seem that both the windfall payments and the supplemental payments would have similar effects.

It is doubtful that deletion of the supplemental payments would materially alter the attitude of a union facing a strike with a pact member who must rely solely upon windfall payments. Similarly, whether a strike will be longer as a result of the carrier receiving both supplemental payments and windfall payments would depend entirely upon the particular carrier involved. It may be that the windfall payments could exceed the standard amount, in which case the supplemental payments would not even be involved. Conversely, it could be that all of the revenue received by a member carier - like Continental - might be entirely made up of supplemental payments. What, then, is the difference in the outcome of the two situations? It is not the type of payment that is crucial to the determination of union attitudes or the length of strikes but, rather, the presence of the payments themselves, regardless of their derivation, that affects such matters. Yet the acceptance of free collective bargaining as the desired method of resolving industrial disputes in our nation is premised upon the use of such private economic weapons. ${ }^{69}$ The establishment of such weaponry in other industries and the periodic exercise of these devices in many bargaining situations are fundamental to our system of resolving industrial conflicts.

The most important criticism of the

${ }^{60}$ See Committee for Economic Development, The Public Interest in National Labor Policy (New York: Committee for Economic Development, 1961), pp. 135-136.
Bureau and of Vice-chairman Murphy in their attack upon the supplemental payments concept centered upon the possibility of a violation of the Railway Labor Act. Unilateral establishment of multiunit bargaining is not, however, explicitly prohibited by the act. Nowhere in the act is there mention of multiunit bargaining. The prohibition stems directly from an administrative interpretation given to the act by the $\mathrm{CAB}$. The opinion of the CAB is based upon the allegation that such bargaining could lead to industry-wide shutdowns which would violate the "public interest" section of the Federal Aviation Act which the CAB is directed to protect. Such a position does not seem tenable. If both the unions and the carriers voluntarily agree to bargain on an industry-wide basis, it would be quite legal under the interpretation given to the act. How can the CAB, then, claim that it is against the "public interest" if the parties are indirectly led to industrywide bargaining, but that it is acceptable if they voluntarily agree to such a development? The potentiality for a shutdown of the entire industry is the same in either case.

In many industries, multiunit bargaining has proven quite successful. In the airline industry, its evolution has been virtually stymied. As a result, the individual carriers have regularly experienced a host of threatened and actual strikes on similar issues. As long as both parties must agree before multiunit bargaining can be introduced, many of the aforementioned negative factors that have given rise to the Mutual Aid Pact are going to continue to disrupt indus. trial relations in the industry.

With reference to the contention that the supplemental payments provision will encourage pact members to seek similar solutions to common problems, 
it is logical to conclude that the pact does provide impetus for such a development. It does not follow, however, that the pact itself provides channels that actually make the achievement of common positions more likely to occur than would be possible in the absence of the agreement. There is no way that one or more pact members can directly influence the labor policies of another carrier except by threatening to withdraw, which would render the issue a moot point.

The pact has several features that are quite desirable for a private bargaining system: membership is open to all trunkline carriers; every facet of the pact is available for public inspection at the offices of the CAB in Washington; all payments and receipts under it must be reported. The administration of the agreement is handled entirely by each individual carrier and does not require any select group possessing arbitrary powers over the actions of the members.

In short, it seems that in this particular industry, the pact is but an outward manifestation of an extremely unstable and insecure labor relations foundation. The public interest could be better served if more attention was directed toward the causes of strikes in this industry rather than the reactions to them. 
Copyright of Industrial \& Labor Relations Review is the property of Cornell University. The copyright in an individual article may be maintained by the author in certain cases. Content may not be copied or emailed to multiple sites or posted to a listserv without the copyright holder's express written permission. However, users may print, download, or email articles for individual use. 